\title{
Spectrophotometric Assay of Noradrenaline in Pharmaceutical Formulation with Alizarin Red Sulphonate
}

\author{
T. S. Al-Ghabsha A. M. S. Al-Delymi \\ Department of Chemistry, College of Education, Mosul University \\ Mosul-Iraq
}

Received

09 / 10 / 2007
Accepted

03 / 12 / 2007

\begin{abstract}
الظلاصة
مق طويرطريقةطيفية بسيطة وسريعة ومسلسة لقدير النورادرينالين. تعتم ـد الطريقة على تقاعل انققل البروتون مع اليزارين لحمر للسلفونت (ARS) في وسط متعال لتكوين نانتج

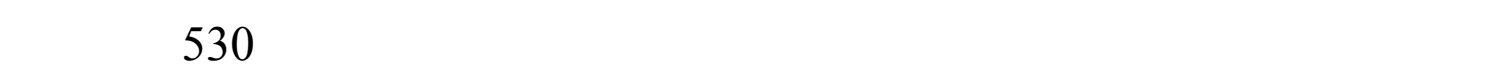

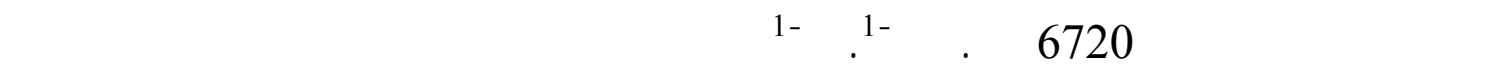

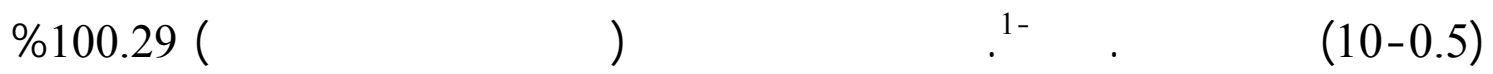

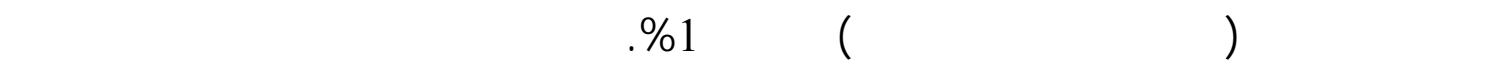
النورادرينالين في المستحضر الصيدلاني كمةن وقم مقارنة النتائج معطريقة الإضلفة القيلسية.
\end{abstract}

\begin{abstract}
A simple, rapid and sensitive spectrophotometric method for the determination of noradrenaline was developed. The method is based on the proton transfer reaction with alizarin red sulphonate (ARS) in aqueous neutral solution to form violet product showing maximum absorbance at $530 \mathrm{~nm}$ with molar absorptivity of $67201 . \mathrm{mol}^{-1} \cdot \mathrm{cm}^{-1}$. The method follows Beer's law over the concentration range $(0.5-10) \mu \mathrm{g} \cdot \mathrm{ml}^{-1}$. The accuracy (average recovery) of the method is $100.29 \%$ and the precision (RSD) of the method is less than $1 \%$.

The method was successfully applied for the determination of noradrenaline in pharmaceutical formulation as injection and the results were in good agreement with the standard addition procedure.
\end{abstract}




\section{INTRODUCTION}

Noradrenaline (NA) is a catecholamine which has been largely recognized to play a very important role in biological system ${ }^{(1)}$. The cells that produce and release NA, namely adrenal chromaffin cells (ACCS), sympathetic postganglionic neurons and central neurons. It plays important roles in learning and memory, and in regulation of cardiovascular activity and nervous system ${ }^{(2,3)}$.

A variety of spectrophotometric methods have been described for the determination of NA. A flow injection analysis technique was used for the determination of NA by its chemiluminogenic oxidation with potassium permanganate in acidic medium in the presence of formaldehyde $^{(4)}$. A spectrophotometric determination of NA based on interference with peroxidase activity, which caused a decrease of the rate of the coupling reaction of p-chlorophenol with 4-aminoantipyrine was described $^{(5)}$. NA was determined spectrophotometrically by nitration with sodium nitrite in slightly acidic solution. When the solution is made basic, an absorption band appears at about $500 \mathrm{~nm}$ with a molar absorptivity of $1 \times 10^{4} 1 . \mathrm{mol}^{-1} \cdot \mathrm{cm}^{-1}{ }^{(6)}$. Another spectrophotometric method for the determination of NA in bulk samples and pharmaceutical preparations, based on their oxidation with iron (III) and subsequent chelation of iron (II) with 2,4,6-tris (2-pyridyl) s-triazine to form violet coloured complex at $595 \mathrm{~nm}$ is described ${ }^{(7)}$.

NA was determined via oxidative coupling by using 2,6-dichloroquinone-chlorimide. The reaction was sensitive to permit the determination of $12 \mathrm{ppm}$ of $\mathrm{NA}^{(8)}$. Ammonium metavanadate ${ }^{(9)}$, sodium bismuthate $^{(10)}$ and sodium periodate ${ }^{(11)}$ were used to determine NA by oxidation producing aminochrome derivative which can be measured spectrophotometrically at 485,486 and $490 \mathrm{~nm}$ respectively.

Recently NA was determined spectrophotometrically using quinalizarin reagent based on proton transfer reaction to form a water soluble violet product which shows maximum absorption at $560 \mathrm{~nm}^{(12)}$. In this paper alizarin red sulphonate (ARS) reagent was used for the spectrophotometric determination of NA via proton transfer reaction in aqueous solution. 


\section{EXPERIMENTAL}

\section{Apparatus}

A Shimadzu UV-210 A digital double beam spectrophotometer with $1 \mathrm{~cm}$ matched quartz cells was used for all spectral and absorbance measurements.

\section{Reagents}

Noradrenaline and ARS (BDH). All other chemicals used were of analytical-reagent grade. Distilled water was used to prepare all solutions except ARS was prepared in absolute ethanol, NA was dissolved in $5 \mathrm{ml}$ of ethanol then completed with distilled water.

\section{Solutions}

NA: $100 \mu \mathrm{g} \cdot \mathrm{ml}^{-1}$ of the pure drug was freshly prepared in aqueous solution (protected from sun light) and used as the standard solution for the analytical purposes.

ARS: $0.001 \mathrm{M}$ was prepared by dissolving $0.0856 \mathrm{gm}$ in $250 \mathrm{ml}$ of absolute ethanol.

\section{Procedure for calibration}

To a series of $10 \mathrm{ml}$ calibration flasks, transfer increasing volumes of NA working standard solution to cover the range $(0.5-10) \mu \mathrm{g} \cdot \mathrm{ml}^{-1}$ in final dilution. Add $2 \mathrm{ml}$ of $0.001 \mathrm{M}$ ARS. Dilute the solution to the mark with D.W. stopper the flasks and shake well, then allow to stand for 5 min. at $40{ }^{\circ} \mathrm{C}$, and the absorbance is measured at $530 \mathrm{~nm}$ against the reagent blank, using $1 \mathrm{~cm}$ cells.

\section{Assay procedure for injection:}

Five ampoules of NA $(1 \mathrm{mg} / \mathrm{ml})$ marked by lab Renaudin-France were mixed well then diluted with distilled water and completed to the mark in a $50 \mathrm{ml}$ volumetric flask, then different volumes used from this solution containing the concentration range $(0.5-10) \mu \mathrm{g} \cdot \mathrm{ml}^{-1}$. After that, the calibration procedure described above was carried out. 


\section{Absorption spectra}

\section{RESULTS AND DISCUSSION}

NA was reacted with ARS to produce a violet coloured proton transfer product with maximum absorption at $530 \mathrm{~nm}$ while the reagent blank shows low absorption at this wavelength (Fig. 1).

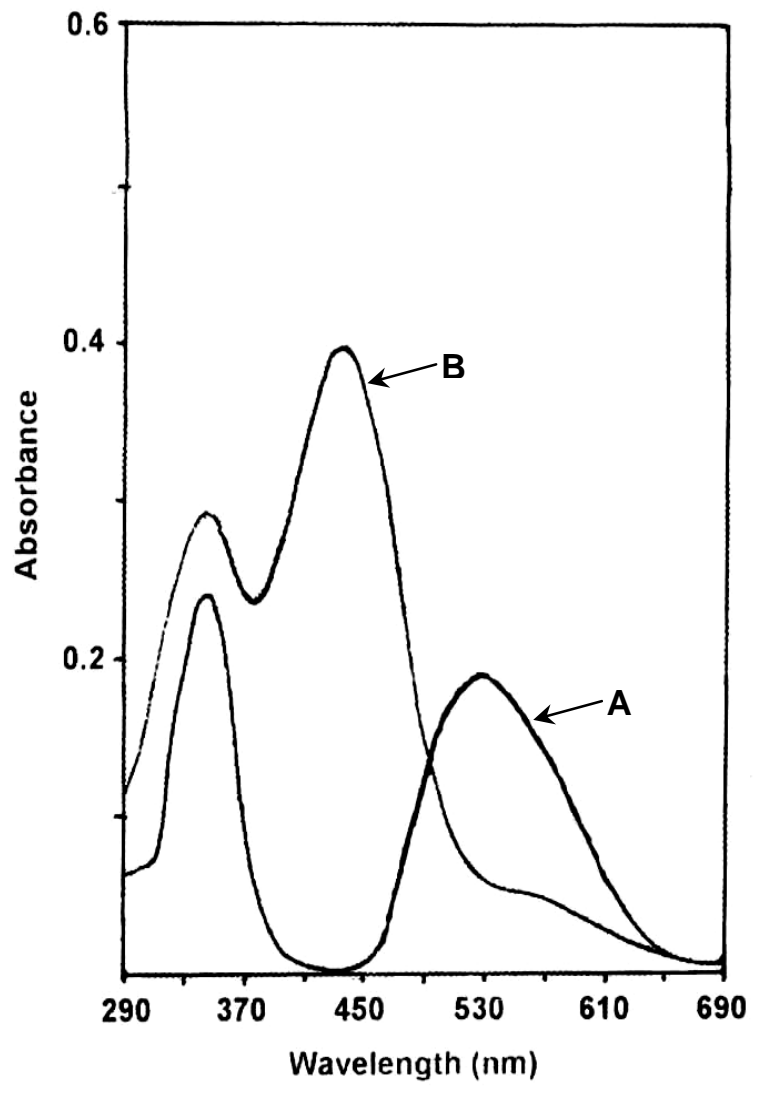

Figure (1): Absorption spectra:

A: Noradrenaline $\left(4 \mu \mathrm{g} \cdot \mathrm{ml}^{-1}\right)$-ARS $\left(2 \times 10^{-3} \mathrm{M}\right)$ product versus reagent blank

B: Reagent blank versus distilled water

\section{Optimization of Conditions}

\section{Effect of buffer}

The $\mathrm{pH}$ of the pure drug was measured, the reading was 7.8 , after addition of $2 \mathrm{ml}$ of ARS the $\mathrm{pH}$ was 7.0, therefore different buffers of $\mathrm{pH}$ 7.0 were prepared such as borate, carbonate, acetate and phosphate. It was found that these buffers decrease the absorbance (Table 1).

Table (1): Effect of buffer on the absorption of product

\begin{tabular}{|c|c|c|c|c|c|}
\hline $\begin{array}{c}\text { Buffer solutions } \\
(\mathrm{pH} 7.0)\end{array}$ & Borate & Carbonate & Acetate & Phosphate & Without \\
\hline Absorbance & 0.023 & 0.018 & 0.031 & 0.027 & 0.170 \\
\hline
\end{tabular}




\section{Effect of temperature and reaction time}

The reaction time was determined by following the colour development at room temperature and in thermostatically controlled water-bath adjusted at 0,40 and $50{ }^{\circ} \mathrm{C}$. The absorbance was measured at 5 mins. intervals against reagent blank treated similarly. It was observed that the absorbance reached maximum after 5 mins. at $40{ }^{\circ} \mathrm{C}$ and remains constant more than 60 mins., and the absorbance decreased slowly thereafter. Hence $40{ }^{\circ} \mathrm{C}$ and reaction time 5 mins., were chosen for colour development (Table 2).

Table (2): Effect of temperature and reaction time

\begin{tabular}{|c|c|c|c|c|c|c|c|c|}
\hline \multirow{2}{*}{$\begin{array}{c}\text { Temp. } \\
\left({ }^{\circ} \mathrm{C}\right)\end{array}$} & \multicolumn{8}{|c|}{ Absorbance } \\
\cline { 2 - 9 } & 5 & 10 & 15 & 20 & 40 & 60 & 80 & 10 \\
\hline 0 & 0.167 & 0.164 & 0.163 & 0.163 & 0.161 & 0.160 & 0.160 & 0.160 \\
\hline RT & 0.169 & 0.172 & 0.172 & 0.175 & 0.177 & 0.177 & 0.175 & 0.173 \\
\hline 40 & 0.178 & 0.178 & 0.178 & 0.178 & 0.178 & 0.178 & 0.176 & 0.176 \\
\hline 50 & 0.178 & 0.177 & 0.177 & 0.175 & 0.177 & 0.170 & 0.168 & 0.165 \\
\hline
\end{tabular}

\section{Effect of ARS concentration}

The effect of different ARS concentrations on the absorbance of solution containing $4 \mu \mathrm{g} \cdot \mathrm{ml}^{-1} \mathrm{NA}$ was studied, it is evident that the absorbance increases with increasing ARS concentration and reached maximum on using $2 \mathrm{ml}$ of $1 \times 10^{-3} \mathrm{M}$ ARS. Therefore, this concentration was used in all subsequent work (Table 3 ).

Table (3): Effect of ARS concentration

\begin{tabular}{|c|c|c|c|c|c|c|}
\hline $\begin{array}{c}\text { ARS solution } \\
1 \times 10^{-3} \mathrm{M}(\mathrm{ml})\end{array}$ & 0.5 & 1 & 1.5 & 2 & 2.5 & 3 \\
\hline Absorbance & 0.153 & 0.162 & 0.169 & 0.178 & 0.170 & 0.168 \\
\hline
\end{tabular}




\section{Effect of surfactant}

The effect of different types of surfactants were used for the improvement of the absorption but the results shown in Table (3) confirm that there is no improvement in the absorption, therefore they were excluded.

Table (4): Effect of surfactant

\begin{tabular}{|c|c|c|c|c|}
\hline \multirow{2}{*}{ Surfactant } & \multicolumn{4}{|c|}{ Absorbance / ml } \\
\cline { 2 - 5 } & 0.5 & 1 & 2 & 3 \\
\hline $\begin{array}{c}\text { Cetyltrimethyl } \\
\text { ammonium bromide } \\
(0.1 \%)\end{array}$ & 0.176 & 0.177 & 0.171 & 0.170 \\
\hline $\begin{array}{c}\text { Sodium dodecyl } \\
\text { sulphate (0.1\%) }\end{array}$ & 0.175 & 0.176 & 0.170 & 0.171 \\
\hline Triton X-100 (1.0\%) & 0.176 & 0.177 & 0.172 & 0.172 \\
\hline Without surfactant & \multicolumn{4}{|c|}{0.178} \\
\hline
\end{tabular}

\section{Analytical data}

Under the proposed experimental conditions, a linear relation between the absorbance and the concentration of NA was observed over the concentration range $(0.5-10) \mu \mathrm{g} \cdot \mathrm{ml}^{-1}$ (Fig. 2) with correlation coefficient of 0.9999 and intercept of 0.0201 . A negative deviation from Beer's law was observed at higher concentrations of NA. The molar absorptivity was $67201 . \mathrm{mol}^{-1} . \mathrm{cm}^{-1}$ (Table 5).

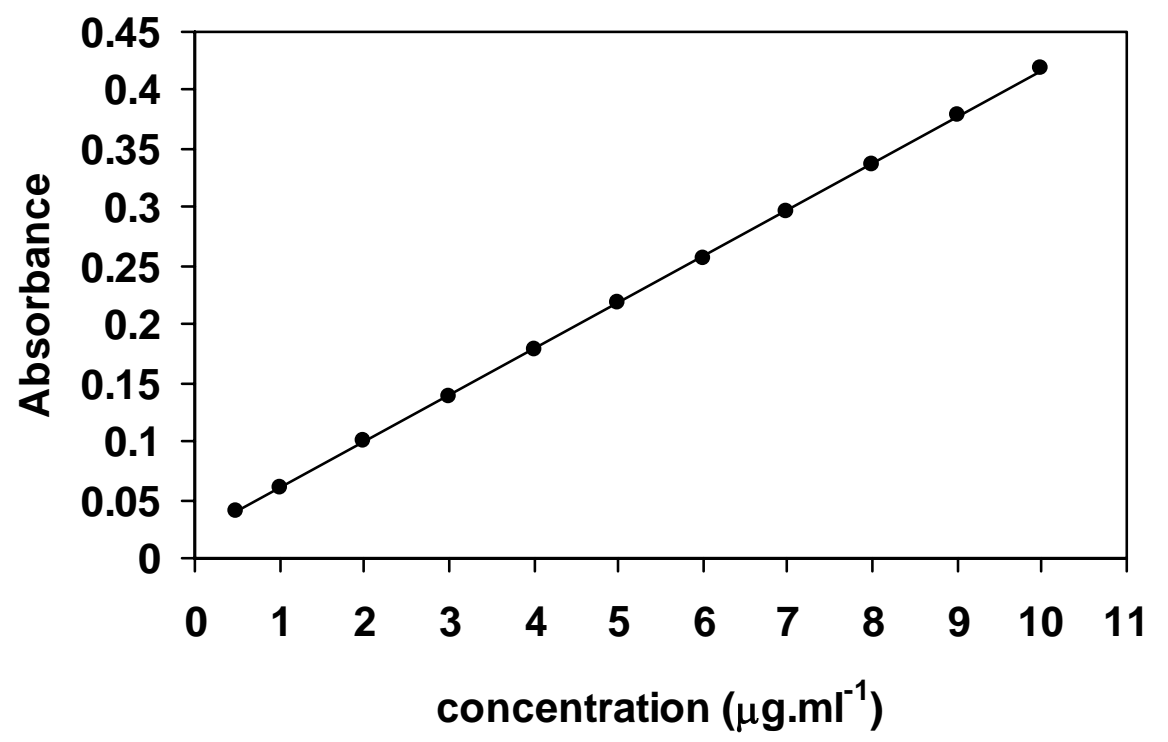

Figure (2): Calibration graph of Noradrenaline 
Table (5): Analytical parameters

\begin{tabular}{|l|c|}
\hline \multicolumn{1}{|c|}{ Parameter } & Noradrenaline \\
\hline Colour & Violet \\
\hline$\lambda_{\max }(\mathrm{nm})$ & 530 \\
\hline Beer's law $\left(\mu \mathrm{g} \cdot \mathrm{ml}^{-1}\right)$ & $0.5-10$ \\
\hline Molar absorptivity $\left(1 . \mathrm{mol}^{-1} \cdot \mathrm{cm}^{-1}\right)$ & 6720 \\
\hline Relative standard deviation $(\mathrm{RSD} \%)$ & $<1$ \\
\hline Average recovery \% & 100.29 \\
\hline Regression equation & \\
\hline Slope & 0.0397 \\
\hline Intercept & 0.0201 \\
\hline Correlation coefficient & 0.9999 \\
\hline
\end{tabular}

\section{Accuracy and precision}

To determine the accuracy and precision of the method, NA was determined at three different concentrations. The results shown in Table(6) referring a satisfactory precision and accuracy.

Table (6): Accuracy and precision of the proposed method

\begin{tabular}{|c|c|c|}
\hline $\begin{array}{c}\text { Amount of NA taken } \\
\mu \mathrm{g} . \mathrm{ml}^{-1}\end{array}$ & Recovery* \% & $\begin{array}{c}\text { Relative standard } \\
\text { deviation* (RSD\%) }\end{array}$ \\
\hline 4 & 101.12 & 0.99 \\
\hline 5 & 100.92 & 0.95 \\
\hline 6 & 98.83 & 0.86 \\
\hline
\end{tabular}

* Average for six determinations

\section{Nature of product and reaction mechanism}

The stiochiometry of the reaction between the drug and ARS was investigated using Job's method ${ }^{(13)}$, the results obtained show that $1: 1$ drug to reagent was formed (Fig. 3).

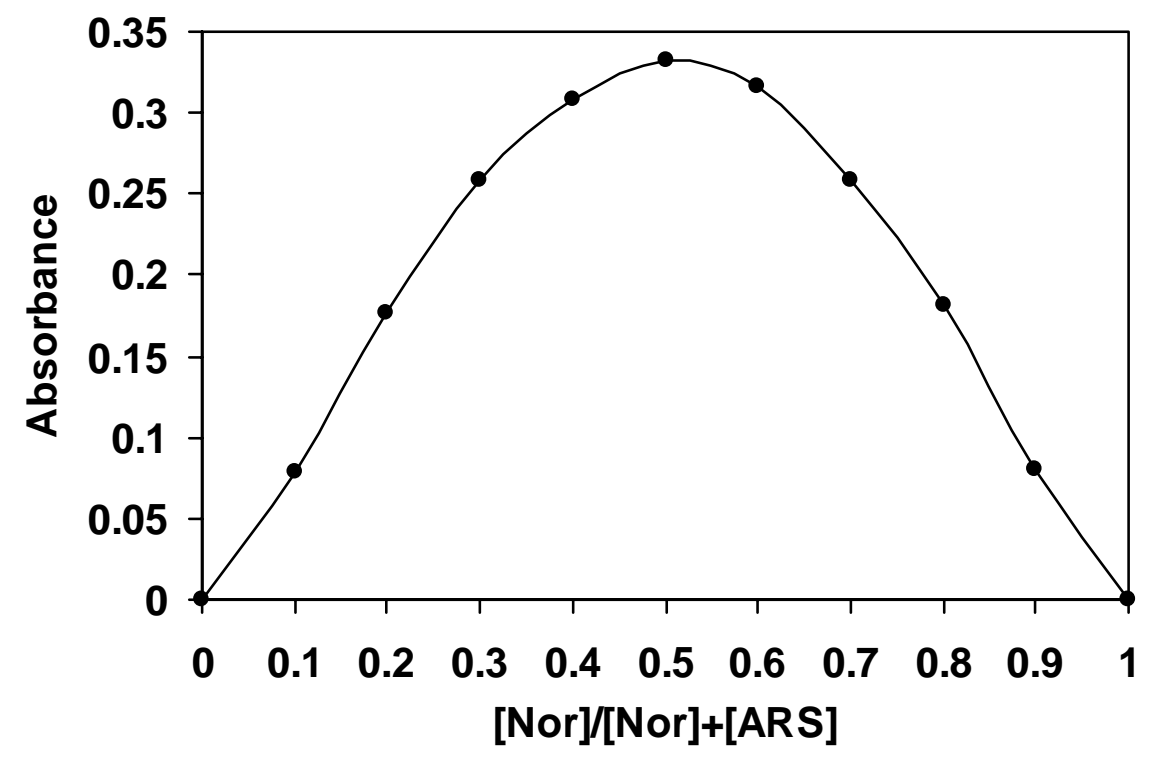

Figure (3): Job's method for noradrenaline-ARS product 
Therefore, the formation of the product may be occur as follows ${ }^{(14)}$ :<smiles>O=C1c2ccc(O)cc2C(=O)c2c1cc([N+](=O)[O-])c(O)c2O</smiles><smiles>NCC(O)c1ccc(O)c(O)c1</smiles><smiles>[14CH3]Oc1cc2c(c(O)c1O)C(=O)c1c(O)ccc(O)c1C2=O</smiles>

The stability constant of the product was estimated and found to be $4 \times 10^{5} 1 . \mathrm{mol}^{-1}$.

\section{Application}

The proposed method was applied to the determination of NA in pharmaceutical injection. Good recovery was obtained and the results compared with the standard addition method (Fig. 4 and Table 4).

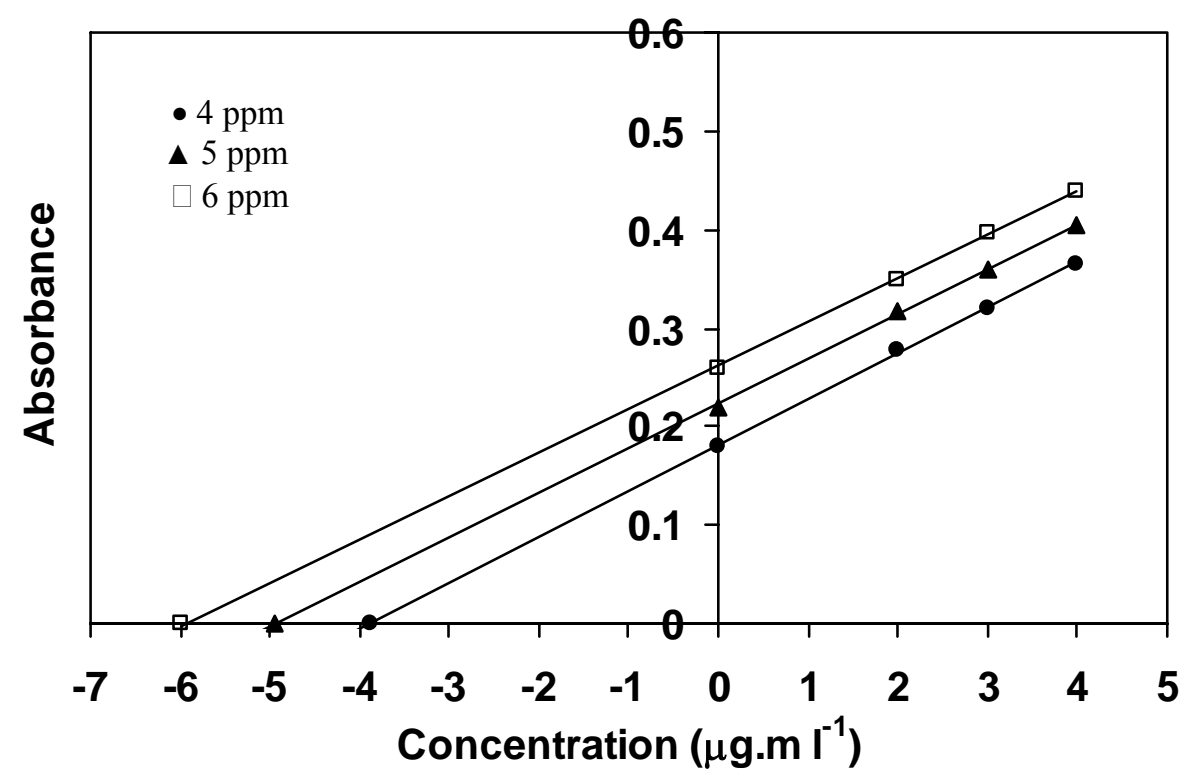

Figure (4): Standard addition graphs of Noradrenaline in pharmaceutical formulation 
Table (7): Assay of Noradrenaline in injection

\begin{tabular}{|c|c|c|c|c|}
\hline \multirow{2}{*}{ Method } & \multicolumn{2}{|c|}{ Amount (mg.ml $\left.{ }^{-1}\right)$} & \multirow{2}{*}{ Recovery $^{(a)} \%$} & \multirow{2}{*}{$\begin{array}{c}\text { Average } \\
\text { recovery }{ }^{(a)} \%\end{array}$} \\
\hline & Certified & Found & & \\
\hline \multirow{3}{*}{ Present } & \multirow{3}{*}{1.0000} & 0.9944 & 99.44 & \multirow{3}{*}{100.14} \\
\hline & & 1.0039 & 100.39 & \\
\hline & & 1.0060 & 100.60 & \\
\hline $\begin{array}{l}\text { Standard } \\
\text { addition }\end{array}$ & 1.0000 & 0.9924 & 99.24 & 99.24 \\
\hline
\end{tabular}

a. Average of three determinations

\section{Comparison of Methods}

Table (8) gives the results obtained by application of the present method and literature method to the determination of noradrenaline in pharmaceutical preparations.

Table (8): Comparison of the present method with other method

\begin{tabular}{|l|c|c|}
\hline \multicolumn{1}{|c|}{ Analytical parameter } & Present method & Quinalizarin method $^{(12)}$ \\
\hline$\lambda_{\max }(\mathrm{nm})$ & 530 & 560 \\
\hline Temp. $\left({ }^{\circ} \mathrm{C}\right)$ & 40 & 40 \\
\hline $\mathrm{pH}$ & Without & Without \\
\hline Development time $(\mathrm{min})$ & 5 & 20 \\
\hline Stability period $(\mathrm{min})$ & 60 & 50 \\
\hline Molar absorptivity $1 . \mathrm{mol}^{-1} . \mathrm{cm}^{-1}$ & 6720 & 6680 \\
\hline Linearity $\left(\mu \mathrm{gg} . \mathrm{ml}^{-1}\right)$ & $0.5-10$ & $1-10$ \\
\hline Recovery $(\%)$ & 100.29 & 99.72 \\
\hline RSD $(\%)$ & $<1$ & $<1.5$ \\
\hline Analytical application & Injection & Injection \\
\hline
\end{tabular}

From the results shown above there is an improvement in the concentration range of the determination in addition to the simplicity, low cost and high sensitivity, also the results show that the present method was faster and does not require solvent extraction.

\section{CONCLUSION}

The reported method is rapid, simple and sensitive. The product formed is stable for at least 60 mins., thus permitting quantitative analysis to be carried out with good reproducibility, also the reported method does not require solvent extraction. 


\section{REFERENCES}

1. Corona-Avendano S., Rojas-Hernandez A., Romero-Romo M.A., Palomar-Pardave M. and Ramirez-Silva M.T., Spectrochimica Acta, Part A: In press, (2005).

2. Zang D., Min Fu, Wanyun M.A. and Chen D., Anal. Sci., 17, 1331, (2001).

3. Teschemacher A.G., Autonomic Neuroscience: Basic and Clinical, 117, 1-8, (2005).

4. Deftereos N.T., Calokerinos A.C. and Efstathiou C.E., Analyst, 118, 627, (1993).

5. Min Zhu, Xuemei Huang, Jie Li and Hanxi Shen, Anal. Chim. Acta, 357 (3), 261 (1997).

6. Barnwn W.D., Anal. Chim. Acta, 89(1), 157, (1977).

7. Sankar D.G., Sastry C.S.P., Reddy M.N. and Aruna M., Ind. J. Pharm. Sci., 50(3), 178, (1988).

8. Sankar D.G., Sastry C.S.P., Reddy M.N. and Prasad S.N.R., Ind. J. Pharm. Sci., 49(2), 69, (1987).

9. Salem F.B., Talanta, 34(9), 810, (1987).

10. Sorouraddin M.H., Manzoori J.L., Kargarzadeh E.K. and Haji Shabani A.M., J. Pharm. and Biomed. Anal., 18 (4,5), 877, (1998).

11. El-Kommos M.E., Mohamed F.A. and Khedr A.S., Talanta, 37(6), $625,(1990)$.

12. Al-Delymi A.M.S., "Development of spectrophotometric methods in organic and drug analysis", Ph.D. Thesis, University of Mosul, (2006).

13. Delevie R., "Principle of Quantitative Chemical Analysis", McGrawHill, New York, p. 498, (1997).

14. Khranina O.V., Chernyakovskii F.P. and Denisov G.S., J. Mol. Struct., 177, 309-315, (1987); Chem. Abst., 111, 5, 38746w, (1989). 